\title{
XXI. Narrative of an excursion to the summit of the peak of Teneriffe on the 23rd and 24th of February 1829
}

\section{Robert Edward Alison Esq.}

To cite this article: Robert Edward Alison Esq. (1830) XXI. Narrative of an excursion to the summit of the peak of Teneriffe on the 23rd and 24th of February 1829, Philosophical Magazine Series 2, 8:44, 140-145, DOI: 10.1080/14786443008675384

To link to this article: http://dx.doi.org/10.1080/14786443008675384

曲 Published online: 10 Jul 2009.

Submit your article to this journal $[\pi$

Џ Article views: 2

View related articles $\sqsubset$ 
Agardh on this subject, they would not fall into absurd and fantastical comparisons, which rest on the same foundation as the ancient analogy detected between the moon and a green cheese, on account of both being round. The learned $\mathrm{Mr}$. Kirby, for instance, in his "Introduction to Entomology," has written in a most flattering manner of my distinction between relations of affinity and analogy; but it grieves me to be obliged to confess that he appears not to understand it, and that his mistake principally proceeds from his forgetting the necessity of parallelism between different relations of analogy. If this respectable naturalist will study the works of Fries, and a little work entitled $D e$ Plantarum prosertim Cryptogamicarum Transitu et Analogia Commentatio," published by Theophilus Gulielmus Bischoff at Heidelberg in 1825, and will then praise me, I shall be gratified by his praise; at present I must say I feel that I do not deserve it, and unmerited approbation is a poor recompense for being made to patronize or father notions that I have no wish to lay claim to.

[To be continued.]

XXI. Narrative of an Excursion to the Summit of the Peak of Teneriffe on the 23rd and 24th of February 1829. By Robert Edward Alison, Esq.

[Continued from p. 30.]

A FTER leaving on our left a steep mountain of pumice, A called Montaña Alta, we passed La Estancia de la Cera and La Cueva de la Machoura, and entered the Cañadas del Pico, the thermometer standing at $50^{\circ} \cdot 5$. The Cañadas is an immense plain of white and yellow pumice, extending round the Peak from W.S.W. to E. by N. forming part of an ellipsis of seven or eight square leagues in extent. The surface is 8957 feet* above the level of the sea; and rather towards one side of this plain, in lat. $28^{\circ} 17^{\prime}$ N., and in lon. $16^{\circ}$ $39^{\prime} 45^{\prime \prime} \mathrm{W}$. rises the Peak to the further elevation of 3231 feet.

At $10^{\mathrm{h}} 30^{\mathrm{m}}$ A. M., thermometer standing at $49^{\circ}$, we passed a mass of porphyritic rocks called La Gayeta, and afterwards some of a similar character, called by the guides La Estancia de Juan Benitiz. Shortly afterwards a thick mist swept across

* This elevation was ascertained by M. Mouneron by levelling, and afterwards confirmed by Humboldt by barometrical admeasurement, calculated by the formula of Laplace. Most of the elevations which I have given here were very kindly furnished me by $\mathrm{Dr}$. Don Domingo Saviñon of Laguna, a physician, who by his various scientific attainments is an honour to his profession. This gentleman has a collection of valuable observations respecting the physical history of Teneriffe, which, it is to be hoped, he will at some future period give to the world. 
us, which lowered the thermometer to $44^{\circ} \cdot 5$ : we at the same time passed a small extinct volcano called Montaña Ncgra, or more generally known by the name of Los Gorros; in it are several caves, which the men who supply Santa Cruz and Orotava with snow, use as ice-houses, by filling them with snow, which they collect at the foot of the Peak at certain seasons of the year: when snow cannot be collected there, they go up to a cave, which is 2131 feet higher up. For four baskets of snow, which is a mulc-load, they obtain at Santa Cruz a sum only equal to $13 s .4 d$. after undertaking a journey of nearly 80 miles, reckoning from their own house and back again. These men likewise act as guides to those who visit the Peak, and are generally found both faithful and obliging.

At twelve o'clock we arrived at the foot of the Peak, and halted for a few minutes. The surface was composed of reddish-coloured pumice, studded over with large blocks of grünsteinic lava of a grayish-green colour, mixed with crystals of felspar, masses of common obsidian, and large bushes of mountain broom. We found the temperature of the air to fluctuate considerably, according as the wind blew away the surrounding vapour. When we first arrived, the thermometer stood at $44^{\circ}$ in the shade; but it shortly afterwards rose to $50^{\circ}$ in the same situation, and to $57^{\circ}$ where it was indirectly exposed to the influence of the sun. A small surface of æther, .25 of a line in depth, and sheltered from the sun and wind, evaporated in rather less than three minutes; and the bulb of a thermometer, covered with silk and kept moist, lowered the mercury three degrees in the same time. When I ascended the Peak on the 13th of October 1827, the same experiments had different results. A similar quantity of æether, and at the same spot, evaporated in about one minute and a half; and the thermometer, enveloped in the same manner, fell $4^{\circ} .5$ in less than three minutes. I found the boiling point of water to be from $189^{\circ} \cdot 5$ to $190^{\circ}$, and strong Havanna rum boiled at $175^{\circ}$; in the town of Orotava (1040 feet above the sea) water boiled at from $209^{\circ} .25$ to $209^{\circ} \cdot 5$. When I ascended the Peak on the 13 th of October 1827 , water boiled at the same spot at $188^{\circ} .5$.

We began to mount the Peak by a very steep ascent over beds of small yellowish-coloured pumice, between two embankments or currents of lava, which had separated from the general mass, called Mal Pais, situated at Alta Vista Arriba, 1664 feet above the foot of the mountain. These currents are not in connected masses, but consist of immense blocks of various sizes and forms; and different parts of the same current appear to have undergone various states of combus- 


\section{$142 \mathrm{Mr}$. Alison's Narrative of an Excursion to the}

tion [?]: some are an obsidian of a jet black colour, possessing internally a shining vitreous lustre, breaking with a conchoidal fracture, and translucent at the edges; others are a brownish porphyritic lava mixed with large crystals of felspar, partly destroyed by the action of fire; others have an earthy appearance, and although cellular, are hard and henvy ; and towards the upper part of the stream were several blocks of phonolite of a greenish gray-colour.

After a fatiguing but not a difficult ascent, which took us three quarters of an hour to accomplish, we arrived at a part of the Peak which is 9930 feet above the level of the sea, called La Estancia de los Ingleses de Abaxo, the lower restingplace of the English : the pumice here forms a tolerably level surface of a few hundred feet square; towards the N.N.E. side of it are scattered several large blocks of obsidian; under the lee of one of them we lighted a fire of dried mountain broom, and piled up some stones to form a shelter from the wind, which was then blowing a hurricane.

One hundred and twenty-eight feet above this Estancia, is another called La Estancia de los Ingleses de Arriba, the upper resting-place of the English, and is to be noticed as the highest point at which the Spartium nubigenum is to be found; after inspecting it, I think this place affords better shelter in summer to a small party of visiters to the Peak, than the one below.

After taking some refreshment, we resumed the ascent with the intention of observing the temperature of the summit that evening, and likewise next morning; the acclivity became more and more difficult, the pumice frequently gave way beneath our feet, and in many places the frozen state of the snow gave us considerable annoyance from the extreme difficulty of climbing up it.

In an hour we arrived at Alta Vista Arriba, which is 10.621 feet above the sea, and is at the end of the surface of pumice, at the point of intersection of the two branches of lava, between which we had been ascending. Here my guide declined to proceed any higher that evening, because we should not be able to arrive at the top of the Peak before dark; and even if we gained the summit, we should be obliged to remain there all night without the slightest shelter, which would have been fatal at that season of the year. I was therefore obliged to defer my journey till next morning, and to retrace my steps to the Estancia.

The remaining hours of light were employed in endeavouring to obtain some shelter from the wind, by forming a wall of lava and pumice: for some time all our various contri- 
vances were useless; as it blew in eddies and frequently scattered our fires : but two hours after sunset the violence of the gale very much abated, and only came in hollow gusts with a noise similar to that of distant thunder in a mountainous country.

My guide and muleteer soon forgot all their fatigues in a peaceful slumber; but the scene around me was so strange and interesting, and my feelings were so closely allied both to pleasure and pain, that sleep was completely banished from my eyes. My imagination took me to that distant period, when the Cañadas upon which the Peak is situated was an inflamed gulf of volcanic matter, twenty miles in circumference, and nearly a thousand feet deep, sending forth on all sides torrents of liquid lava, raising plains into high mountains or sinking elevated lands into valleys, and creating by degrees the celebrated volcano upon which I was placed, and which must have so frequently threatened destruction to the interesting people who were so cruelly exterminated by the sword of the Spaniards. But everything around me was now calm and placid : the valleys and mountains below were hidden from my view by white fleecy clouds, which had the appearance of an immense plain of snow some hundred square miles in extent; and towering above this sea of vapours, like rocks in the ocean, were the elevated lands of Canary, the mountain of Angostura* in the Cumbre, Montaña Blanca $\uparrow$ above the Valley of Orotava, Pedrogil $\neq$ on the S.E. side of the same valley, and the Risco of Guajara $\S$, which is a part of the elevated chain of mountains surrounding the Cañadas from F. to W.S.W. From the refractive state of the atmosphere, these elevations appeared to be higher than they actually were. This was particularly marked by the neighbouring mountain of Guajara, which is only nineteen feet higher than the Estancia; yet at night it appeared to be considerably above it.

The blueness of the zenith was such, that a person who had not witnessed it would have supposed it unnatural if he had seen it represented in a picture; and from the clearness of the atmosphere, the light given by the stars and planets was sufficient to enable me to see to write my observations; and Venus left a faint glimmering of light on a wreath of snow near my resting-place; and when the moon, which was just entering her first quarter, arose, I could distinctly see the degrees

* Which is 7070 feet above the level of the sea.

$\uparrow$ Which is 6731 feet above the level of the sea.

7 Which is 6148 feet above the level of the sea.

$\$$ Which is 9949 feet above the level of the sea. 
upon my thermometer. Another still stronger proof of the extreme clearness of the atmosphere is, that I observed the moon to be indented like a saw, between the light and obscure part, which I suppose was caused by the projection of the enlightened tops of her mountains upon the part which was deprived of the sun's light. At first I thought it was some optical illusion, as I had just before been standing before the fire, and was almost blind by the smoke; but repeated observations which I made during the night convinced me that $I$ was right in what $\mathrm{I}$ first observed.

There is another observation which I made that may be worth mentioning. Soon after the sun went down the wind became much louder and had an acuter sound, although the force was very considerably less than in the day-time. It has been observed from the earliest antiquity, that the air becomes more sonorous at night than in the day; but I am not aware that the cause of it is well ascertained. The general opinion, I believe, is, that the air becoming colder, is therefore denser and more susceptible of conveying the sonorous waves. This to a certain extent may be correct, as it has been well ascertained by Dr. Priestley, that the force of the pulsations of sound depends considerably upon the degree of density or rarefaction of the air; and I think Captain (now Sir Edward) Parry mentions the surprising distance he was enabled to hear sound during the winter at the North Pole. From frequent observations which I have made in Teneriffe, I am inclined to attribute the intensity of sound. at night to a certain increase of moisture, and to an equability of temperature in the different strata of the atmosphere. The increased intensity of sound, when I was on the Peak during the night, could not have been caused by an increased density of the atmosphere; because instead of becoming colder, it was four or five degrees warmer when the sound of the wind became more sonorous. Humboldt has made a similar remark; and as my observations fully coincide with his opinion, I beg to quote it. He ascribes the diminution of sound during the day to the presence of the sun, which influences the propagation and intensity of sound, by opposing to them currents of air of different density, and partial undulations of the atmosphere produced by unequal heating of different parts of the ground. In these cases a wave of sound, when it meets two portions of air of different density, is divided into two or more waves, a part of the primitive wave being propagated with more rapidity through the clenser portions than the parts that pass throngh air of less density. In this way the wave is broken down into different parts, which arrive at the ear at different times. These different portions 
of the wave passing again through succeeding portions of the atmosphere of different density, may be so wasted and frittered down as to be incapable of affecting the tympanum.

My observation respecting the intensity of sound is not confined to the Peak. At the town of Orotava, situated about two miles from the sea, the noise of the waves in the morning occasionally had a grave low tone: at the same time the air appeared to be particularly $d r y$, and distant objects were very indistinct. Towards the middle of the day, or the beginning of the afternoon, the island of Palma, nearly sixty miles distant, could be distinctly seen; and the ridge of mountains that surround the valley of Orotava were apparently brought so close, that the vegetation upon them could be observed: at the same time the sound of the sea invariably passed from a grave to an acute sound. The natives prognosticate rain when this particular clearness of the atmosphere takes place; and I have generally found them correct.

But to return from my digression. At various times in the night I observed meteors, like rockets, with luminous points, shooting about in the atmosphere, apparently at an elevation not much greater than the top of the Peak. 'Their appearance was different from those ignited vapours commonly called falling-stars, and their course was different, as they generally moved in a horizontal direction.

At no period of the night did the thermometer fall below $34^{\circ}$, and the average height of it from 5 P.M. to 5 A.M. was $37^{\circ}$; but from the great rarefaction of the air, it appeared by the feelings to be considerably below the freezing point.

[To be continued.]

\section{Notices respecting Nerw Books.}

\section{A Treatise on Hydrosiatics and Hydrodynamics for the Use of} Students in the University. By H. MOSELEY, B.A. of St. John's College. Cambridge, 1830.

THIS work contains a proposition deserving of notice, as being 1 in a great measure new, and of considerable importance in the theory of the motion of fluids. The proposition may be thus generally stated:-If fluid of any kind be moving in such a manner that at the same point in space the velocity is constantly the same in quantity and direction, and if $x, y, z$, be the forces impressed at any point whose coordinates are $x, y, z$, and $v$ be the velocity at this point, then will

$$
\int \frac{d p}{\rho}=\int(\mathrm{X} d x+\mathrm{Y} d y+\mathrm{Z} d z)-\frac{v^{2}}{2}+c
$$

Euler has given in the Berlin Memoirs, 1755, a proof of this theorem for incompressible fluids, seemingly without being aware N.S. Vol. 8. No. 44. Ang. $1830 . \quad U$ that 